\title{
Dermoscopy examination of petechial lesions in a patient with Dermatitis Herpetiformis
}

\author{
Exame dermatoscópico de lesões petequiais num paciente com \\ Dermatite Herpetiforme
}

Paulo Ricardo Criado ${ }^{1}$
Nilton Gioia Di Chiacchio²

Leopoldo Duailibe Nogueira Santos ${ }^{2}$

Abstract: An uncommon skin manifestation of Dermatitis Herpetiformis is palmar and plantar purpura. Dermoscopic examination is useful for any skin condition since it allows recognition of structures that are not discernible to the naked eye. A 22 year-old Caucasian man was admitted with excoriated lesions and pruritus. Petechial lesions could be seen on volar aspect of the digits on the hands and feet. Dermoscopy examination revealed erythematous and violaceous dots and erythematous and brown dots.

Keywords: Celiac disease; Dermatitis herpetiformis; Dermoscopy; Purpura; Skin diseases, vesiculobullous

Resumo: Púrpura palmar e plantar é uma manifestação cutânea incomum da Dermatite Herpetiforme. A dermatoscopia é útil para o exame dermatológico por permitir o reconhecimento de estruturas que ao olho nu não são perceptíveis. Doente caucasiano masculino de 22 anos que queixava-se de lesões escoriadas e prurido. Observouse na face volar dos dedos dos pés e das mãos lesões petequiais. O exame dermatoscópico revelou pontos eritematosos e violáceos, além de pontos eritematosos e marrons.

Palavras-chave: Dermatite herpetiforme; Dermatopatias vesiculobolhosas; Dermoscopia; Doença celíaca; Púrpura

\section{INTRODUCTION}

Dermatitis herpetiformis (DH) was initially described by Louis Duhring in $1884 .{ }^{1} \mathrm{DH}$ most commonly presents as a symmetric, pruritic, papulovesicular eruption on the extensor surfaces of children and adults., ${ }^{2,3}$ An uncommon skin manifestation of $\mathrm{DH}$ is palmar and plantar purpura. The dominant hand often appears more involved, suggesting trauma as an etiologic factor. ${ }^{4}$

Dermoscopic examination is a useful tool for visualization of any skin condition since it allows recognition of structures that are not discernible to the naked eye.

\section{CASE REPORT}

We report a clinical case where purpuric lesions on the hands of a patient with $\mathrm{DH}$ were examined under dermoscopy.

A 22 year-old Caucasian man with one and a half year history of generalized excoriated cutaneous lesions was admitted with intense pruritus. Numerous excoriated papules and crusts were distributed on the scalp, neck, dorsum, extensor surface of the limbs, in addition to the lumbar and intergluteal areas. Petechial lesions on the volar aspect of the digits of the hands and feet were visible (Figure 1). Dermoscopy examination (DermLite Photo; 3Gen) of

\footnotetext{
Received on 27.08.2012.

Approved by the Advisory Board and accepted for publication on 04.10.2012.

* Work performed at the Dermatology Division of the Hospital das Clínicas of the University of São Paulo School of Medicine (HC-FMUSP) - São Paulo (SP), Brazil.

Conflict of interest: None

Financial funding: None

PhD. Physician in the Dermatology Division of the Hospital das Clínicas of the University of São Paulo School of Medicine (HC-FMUSP) - São Paulo (SP), Brazil.

Physician. Postgraduate in Dermatology, Taubaté University Hospital - University of Taubaté (HUT-UNITAU) - Taubaté (SP), Brazil.

C 2013 by Anais Brasileiros de Dermatologia
} 
the volar surface of the fingers revealed erythematous and violaceous dots (new petechial lesions) and erythematous and brown dots (old petechial lesions) (Figure 2). The patient's medical history included hypothyroidism. He presented no gastrointestinal symptoms. He was right-handed.

The vicinity of a purpuric lesion on the second finger of his right hand was biopsied. Hematoxilineosin stain revealed a subepidermal vesicle with neutrophils infiltrate in the dermal papillae (Figure 3A). Direct immunofluorescence exam of the apparently normal perilesional skin revealed granular IgA deposits on the upper dermis (Figure 3B). The serum level of anti-transglutaminase IgA antibodies was $18 \mathrm{U} / \mathrm{ml}$ (ELISA, normal range: under $10 \mathrm{U} / \mathrm{ml}$ ) and G6PD was normal. Dapsone 100mg per os was initiated. After 3 days, there was no pruritus, and a glutenfree diet was accepted. On the 20th day of treatment, we saw only residual hyperpigmentated lesions.

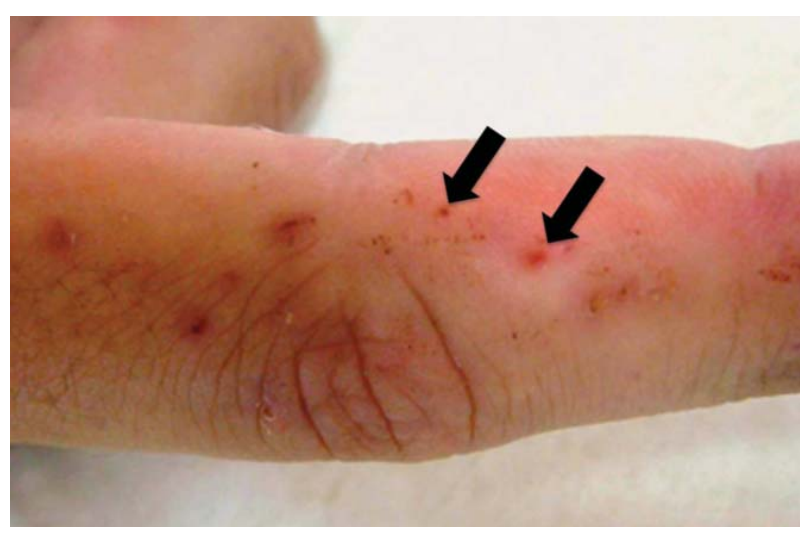

FIGURE 1 : Dermatitis Herpetiformis. Petechial lesions on the finger

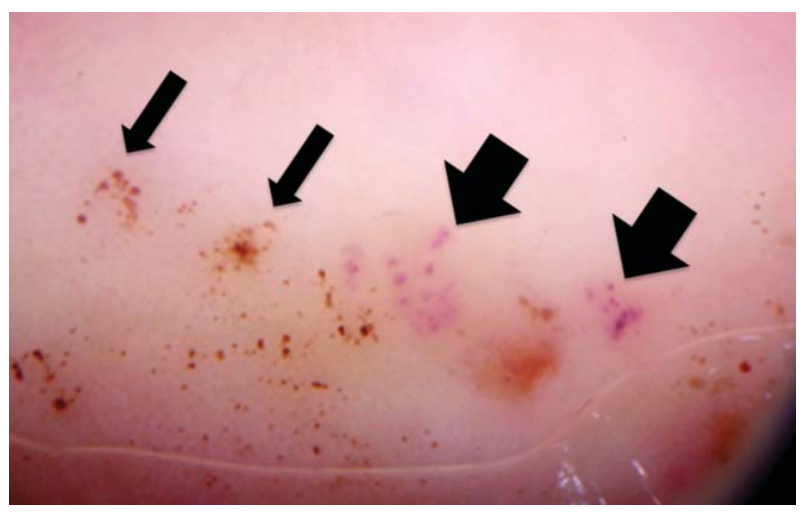

FIgURE 2 : Dermatitis Herpetiformis. Under dermoscopy exam (DermLite Photo; 3Gen), erythematous and violaceous dots can be seen (New petechial lesions, thick arrows) and erythematous and brown dots (Old petechial lesions, thin arrows)
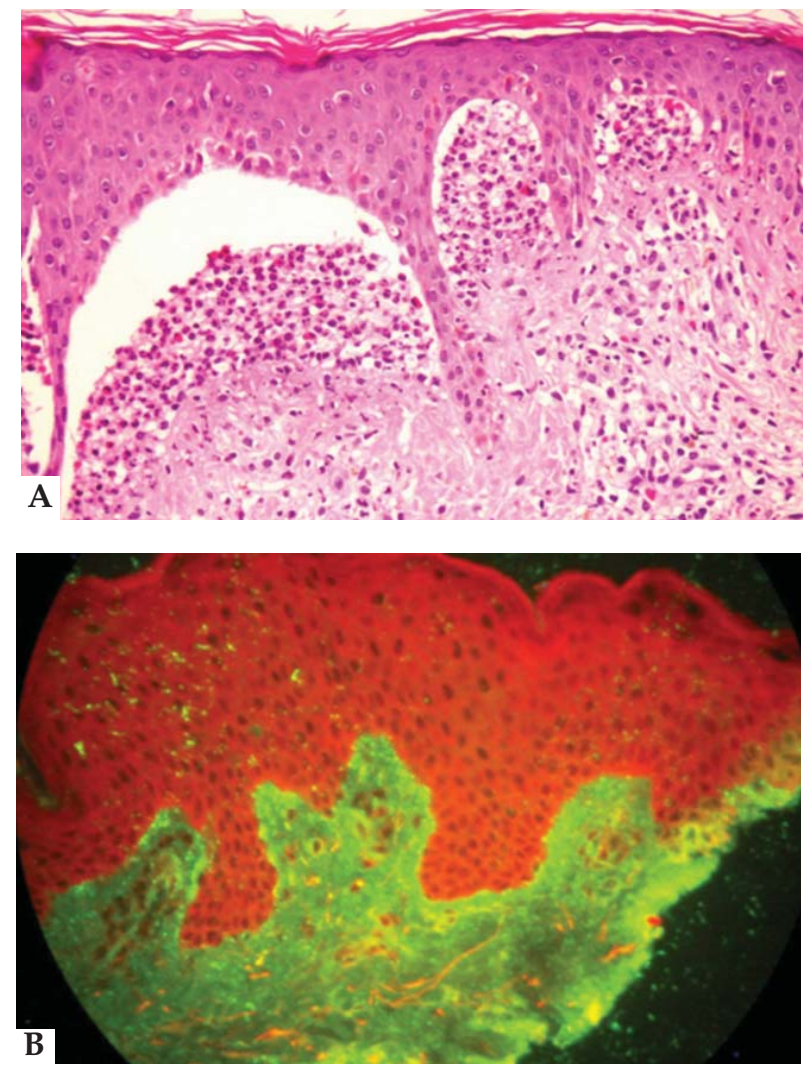

Figure 3 : Dermatitis Herpetiformis. A. (Hematoxylin and Eosin, 100x) subepidermal vesicle with neutrophilic infiltrate in the papillary dermis. B. (Direct immunofluorescence): IgA deposit in a granular pattern in the upper dermis

\section{DISCUSSION}

A Hungarian group presented a large series of children with $\mathrm{DH}$ displaying hemorrhagic palmar lesions, with the right palm and index finger more involved. Mechanical factors were thought to exacerbate the lesions, and the right-sided predominance could probably be ascribed to most patients being right-handed. ${ }^{5}$

The atypical palmar and plantar purpura presentation of DH has been reported in the literature by many authors. However, description of the dermoscopy examination has never been reported. Vazquez-Lopez et al recently revised the dermoscopic patterns of purpuric lesions, but did not describe lesions similar to those cited above. ${ }^{6}$

Our case suggests that dermatologists need to perform a careful dermoscopy exam of the hands and feet in order to find new clues in cases where DH is a possible diagnosis. 


\section{REFERENCES}

1. Duhring LA. Landmark article, Aug 30, 1884: Dermatitis herpetiformis. By Louis A. Duhring. JAMA. 1983;250:212-6.

2. McGovern TW, Bennion SD. Palmar purpura: an atypical presentation of childhood dermatitis herpetiformis. Pediatr Dermatol. 1994;11:319-22

3. Cunha PR, Barraviera SR. Autoimmune bullous dermatoses. An Bras Dermatol. 2009;84:111-24

4. Bolotin D, Petronic-Rosic V. Dermatitis herpetiformis. Part I. Epidemiology, pathogenesis, and clinical presentation. J Am Acad Dermatol. 2011;64:1017-24.

5. Karpati S, Torok E, Kosnai I. Discrete palmar and plantar symptoms in children with dermatitis herpetiformis Duhring. Cutis. 1986;37:184-7.

6. Vazquez-Lopez F, García-García B, Sanchez-Martin J, Argenziano G. Dermoscopic patterns of purpuric lesions. Arch Dermatol. 2010;146:938.

MAILING ADDRESS:

\section{Paulo Ricardo Criado}

Av. Dr. Enéas de Carvalho Aguiar, 255, $3^{\circ}$ andar, Cerqueiras César 05403-900 - São Paulo - SP

Brazil

E-mail:prcriado@uol.com.br

How to cite this article: Criado PR, Di Chiacchio NG, Santos LDN. Dermoscopy examination of petechial lesions in a patient with Dermatitis Herpetiformis. An Bras Dermatol. 2013;88(5):817-9. 